\title{
PENGARUH KEPEMIMPINAN, DISAIN PEKERJAAN, DAN IKLIM ORGANISASI TERHADAP KEPUASAN KERJA TENAGA PENUNJANG AKADEMIK DI UNIVERSITAS NEGERI MEDAN
}

\author{
Irsan
}

\begin{abstract}
The objectives of this research were to find out: (1) the effect of leadership on job satisfaction, (2) the effect of job design job satisfaction, (3) the effect of organizational climate on job satisfaction; (4) the effect of leadership on organizational climate; and (5) the effect of job design on organizational climate. The study was a survey conducted in Medan with 79 sample of Medan University employees, selected randomly. The data were analyzed by using path analysis. The result of this research were as follows: (1) there was a positive effect of leadership on job satisfaction; (2) there was a positive affect of job design on job satisfaction; (3) there was a positive effect of organizational climate on job satisfaction; (4) there was a positive effect of leadership on organizational climate; and (5) there was a positive effect of job design on organizational climate. In order to improved job satisfaction, leadership in line with context and situation, the relevant job design, and the conducive organizational climate should be put into human capital management; however other variables were necessary to be taken into account by next job satisfaction research.
\end{abstract}

Keywords: Leadership, Job Design, Organizational Climate, Job Satisfaction.

\section{PENDAHULUAN}

Saat ini Indonesia memasuki era pelayanan publik setelah disahkannya Undang-Undang No. 25/2009 tentang Pelayanan Publik yang menjadi rujukan kebijakan nasional. Pelayanan publik menjadi soko guru peningkatan kepercayaan masyarakat terhadap pemerintah. Kinerja pemerintah, baik negara maju maupun di negara berkembang, selalu diukur melalui pemberian pelayanan dasar meliputi pendidikan, kesehatan, dan lain-lain. Meskipun usaha peningkatan pelayanan merupakan manifestasi konkrit dalam tata kelola pemerintahan yang baik, pemerintah harus berjuang mengatasi banyak tantangan dan keterbatasan.Infrastruktur dan sumber daya pelayanan publik sering disebut sebagai modal utama dalam pemberian pelayanan publik yang baik.

Perguruan tinggi, baik negeri maupun swasta, juga melaksanakan pelayanan publik di bidang pendidikan. Perguruan tinggi juga dihadapkan kepada globalisasi yang ditandai dengan tantangan dan persaingan semakin berat dan kompleks yang diakibatkan oleh ekspansi pasar internasional dalam bidang pendidikan dan dinamika internal pendidikan di dalam negeri. Globalisasi, menurut Stiglitz, merupakan interdependensi yang tidak simetris antar negara, lembaga dan aktornya, serta bercorak fundamen-talisme pasar (Stiglitz, 2003:33). Tenaga kependidikan perguruan tinggi dituntut untuk memiliki kinerja yang baik agar proses pendidikan berlangsung sesuai dengan yang diharapkan. Proses pendidikan yang baik didukung manajemen yang tepat, sarana prasarana, sumber daya manusia, dan lingkungan yang kondusif. Analisis terhadap sistem pendidikan tinggi dengan menggunakan pendekatan sistem adalah salah satu cara yang mungkin dilakukan untuk menemukan kelemahan yang terjadi

- Dosen Universitas Negeri Medan 
dalam sistem pendidikan. Salah satu komponen yang patut dipahami kekuatan dan kelemahannya adalah tenaga penunjang akademik. Penulis tertarik mengkaji komponen ini karena tenaga tenaga penunjang akademik merupakan komponen strategis dalam mendukung keberhasilan proses dan hasil pendidikan. Tenaga penunjang akademik bertugas melaksanakan administrasi, pengelolaan, pengembangan, penga-wasan, dan pelayanan teknis untuk menunjang proses pendidikan pada satuan pendidikan (UU No. 20 Tahun 2003). Manajemen sumber daya manusia di perguruan tinggi harus dilakukan secara konsisten dan berkesinambungan, untuk menciptakan individu-individu yang memiliki kompetensi di bidangnya.

Usaha untuk memahami masalah-masalah tenaga kependidikan dimulai dari suatu kenyataan bahwa setiap manusia individu mempunyai hal-hal khusus mengenai sifat, tabiat dan kebiasaan-kebiasaan yang tumbuh dan dibentuk oleh lingkungan.Sikap, tabiat, kebiasaan, kepentingan dan tuntutan bukan hanya milik seorang karyawan tetapi milik mereka bersama dalam suatu kelompok. Rasa kebersamaan sebagai kelompok menyebabkan para karyawan menun-jukkan tanggapan yang sama terhadap sesuatu yang terjadi disekitar mereka.

Salah satu gejala yang dapat mengganggu kondisi dalam suatu organisasi adalah rendahnya kepuasan kerja (job satisfaction) anggota organisasi.Dalam bentuknya yang lebih ekstrim gejala itu dapat muncul dalam mogok kerja, bekerja lamban, mangkir, pindah kerja, berperilaku negatif terhadap organisasi.Sebaliknya, kepuasan kerja yang tinggi diinginkan oleh para manajer karena dapat dikaitkan dengan hasil positif yang mereka harapkan.Kepuasan kerja yang tinggi merupakan tanda bahwa organisasi dikelola dengan baik dan pada dasarnya merupakan hasil manajemen perilaku yang efektif.Kepuasan kerja adalah perasaan orang tentang pekerjaan dan aspek-aspek yang bervariasi dari pekerjaan mereka (Spector, 1997). Dengan kata lain, kepuasan kerja dapat dipahami sebagai perasaan umum tentang pekerjaan atau sebagai kumpulan sikap yang berhu-bungan dengan aspek-aspek pekerjaan. Kepuasan kerja karyawan merupakan tolok ukur yang penting dalam rangka perencanaan strategis sumber daya manusia yang akan datang. Melihat pentingnya kepuasan kerja karyawan dalam rangka lancarnya organisasi, maka perlu membahas bagaimana kepuasan kerja karyawan organisasi dapat berjalan dengan baik dan lancar.

Hasil penelitian di Amerika Serikat menunjukkan bahwa tingkat kepuasan kerja karyawan menurun dari 58 persen pada 1995 menjadi 49 persen pada 2003 (Korenzt, 2003:40). Hanya sekitar 20 persen dari mereka yang disurvai pada 2003 merasa puas dengan dengan promosi dan bonus yang berikan organisasi, dan sekitar 33 persen puas dengan gaji yang mereka terima. Terjadinya penurunan kepuasan karyawan ini karena meningkatkanya harapan tentang apa yang ingin dicapai karyawan dari pekerjaan mereka. Fakta lain tentang tingkat kepuasan kerja sangat bervariasi antar berbagai negara, dan pada umumnya berada pada level yang rendah. Contoh: 65 persen karyawan di Scandinavia puas dengan pekerjaan mereka, sementara di Francis 61 persen, di Swiss dan Italia hanya 53 persen, dan di Jerman 50 persen (http://www.wissinfo, 2005); sementara di sisi lain 60 persen karyawan di Kanada merasa puas dengan pekerjaan, sedangkan di wilayah Asia-Pasifik sebanyak 61 persen (http://www.watsonwyatt.com/research, 2006).

Menurut Mullins, kepuasan kerja merupakan konsep yang kompleks dan sulit diukur secara objektif karena kepuasan kerja dipengaruhi berbagai faktor yaitu faktor individu, organisasi, sosial, kultur, lingkungan, dan faktor khusus (Mullins, 2005:701). Lebih lanjut Mullins menegaskan pula tentang masing-masing faktor dimaksud.Faktor 
individu meliputi pendidikan, kepribadian, kemampuan, umur, status perkawinan, dan orientasi kerja. Faktor organisasi meliputi keadaan dan ukuran, struktur formal, kebijakan personalia dan prosedur, keadaan pekerjaan, teknologi, organisasi kerja, gaya kepemimpinan, supervisi, sistem manajemen. Faktor sosial meliputi relasi dengan karyawan, kelompok kerja dan norma, peluang untuk berinteraksi, dan organisasi informal. Faktor kultur meliputi sikap, keyakinan, dan nilai. Faktor lingkungan meliputi ekonomi, sosial-budaya, dan pemerintah.Sedangkan faktor khusus meliputi teknologi informasi, stress dalam pekerjaan, organisasi kerja, job design, pendekatan organisasi, keseimbangan kerja dan keseimbangan hidup, fleksibilitas pengaturan kerja, dan faktor kontekstual.Steers menegaskan bahwa faktor penentu kepuasan kerja meliputi dua faktor utama yaitu karakteristik karyawan dan iklim organisasi (Steers, 1977:96).Lebih lanjut dia menegaskan bahwa iklim organisasi dipengaruhi pula oleh kebijakan dan praktek manajemen, struktur organisasi, teknologi, dan lingkungan eksternal.Struktur organisasi berkaitan pula dengan beban tugas, jenis, dan disain pekerjaan.

Dengan demikian dipahami bahwa kepuasan kerja karyawan dipengaruhi oleh banyak variabel, seperti: struktur organisasi, karakteristik karyawan, motivasi kerja, disain pekerjaan, iklim organisasi, perilaku pemimpin atau kepemimpinan, dan lainlain. Selain kepemimpinan, variabel penting lain yang berperan dalam mempengaruhi kepuasan karyawan adalah disain pekerjaan (job design). Job design, termasuk dalam kategori faktor khusus yang mempengaruhi kepuasan kerja. Disain pekerjaan merupakan cara yang digunakan manajemen untuk mengembangkan dan menetapkan isi pekerjaan, meliputi seluruh tugas yang relevan maupun proses dimana pekerjaan disusun dan direvisi (Luthans, 2008:344). Tujuannya adalah untuk memaksimumkan efisiensi dalam pekerjaan.Taylor mendukung disain pekerjaan menjadi unsur utama pekerjaan yang terkenal dalam manajemen ilmiah. Adanya disain pekerjaan menunjukkan pentingnya peningkatan penerapan teknik dalam mempelajari perilaku organisasi, khususnya dalam memperjelas kecen-derungan aktual yang bervariasi.

Variabel lain yang diduga kuat mempengaruhi kepuasan kerja karyawan adalah iklim organisasi itu sendiri. Iklim organisasi merupakan gambaran kondisi lingkungan dalam organisasi dan atau suasana kerja yang dirasakan karyawan. Suasana dimaksud dapat berupa kekompakan sesama karyawan, hubungan pimpinan-bawahan, kondisi lingkungan fisik, jam kerja, dan keamanan dalam bekerja. Situasi ini selalu dirasakan oleh karyawan karena situasi ini dapat mereka jadikan sebagai motivator atau penghalang dalam bekerja, dan memiliki pengaruh terhadap aspek lain dalam pekerjaan.

Universitas Negeri Medan (UNIMED) merupakan salah organisasi lembaga pendidikan tinggi yang bertujuan untuk menghasilkan lulusan yang unggul dan profesional.Dalam rangka pencapaian tujuan tersebut, maka salah satu misi UNIMED adalah untuk membina suasana akademik dan iklim organisasi yang sehat (Djamin, 2007:1).Akan tetapi, masih perlu dianalisis secara mendalam apakah pembinaan suasana akademik dan iklim organisasi yang sehat dimaksud telah dilaksanakan dengan sungguh-sungguh.

Dalam bidang administratif, peningkatan pelayanan prima telah dijadikan sebagai salah satu kegiatan dalam tata kelola Universitas, demikian juga dengan kegiatan pembinaan staf untuk meningkatkan ketaatan terhadap kebijakan dan aturan akademik.Guna mendukung pelayanan prima, sebagai hakekat pelayanan publik, telah dibangun berbagai fasilitas pendukung akademik, dan dikembangkan pula sistem manajemen data terintegrasi berbasis teknologi informasi. 
Studi yang mendalam terhadap kepuasan kerja tenaga penunjang akademik serta faktor-faktor yang mempengaruhinya perlu dilakukan secara sistematis di Universitas Negeri Medan. Jika analisis komprehensif tentang hal ini dilakukan, maka di masa yang akan datang diharapkan pihak manajemen dapat merancang, mempertahankan, dan/atau merubah kepuasan kerja tenaga penunjang akademik di Universitas Negeri Medan ke arah yang diinginkan.

Kepuasan Kerja. Dalam studi pengembangan organisasi (organizational developmnet), kepuasan kerja dapat dikatakan sebagai variabel yang berkaitan dengan kinerja maupun efektivitas organisasi. Menurut Spector (1997:2), kepuasan kerja adalah perasaan orang tentang pekerjaan dan aspek-aspek yang bervariasi dari pekerjaan mereka. Secara umum kepuasan kerja mengacu pada sikap umum seseorang terhadap pekerjaannya (Robbins dan Coulter, 2007: 421). Menurut Newstrom dan Davis (2002:208) kepuasan kerja adalah sikap peribadi seseorang yang bersifat khusus karena kepuasan kerja merupakan bagian dari kepuasan hidup. Lebih tegas pengertian kepuasan kerja dikemukakan oleh Locke sebagaimana dikutip oleh Luthans (2008: 141) yaitu sesuatu yang keadaan perasaan positif atau menyenang-kan seseorang yang dihasilkan dari penilaian pekerjaannya atau pengalaman kerjanya sendiri.

Colquitt, Lepine dan Wesson (2009:104) berpendapat bahwa kepuasan kerja adalah ungkapan perasaan senang atas penilaian terhadap suatu pekerjaan atau pengalaman kerja. Dalam arti lain, kepuasan kerja merupakan reprensentasi tentang perasaan terhadap pekerjaan dan apa yang dipikirkan terhadap pekerjaan tersebut. Sementara Grenberg dan Baron (1999:170) mendefinisikan kepuasan kerja sebagai reaksi kognisi, afeksi dan evaluasi individu-individu terhadap pekerjaan mereka. Fred Luthans (2002:230) juga berpendapat bahwa kepuasan kerja meliputi reaksi kognitif, afektif, dan evaluatif terhadap suatu pekerjaan.Reaksi yang menyenangkan atau tidak menyenangkan diakibatkan oleh penilaiannya terhadap pekerjaan tersebut. Oleh karena itu, Luthans lebih lanjut menjelaskan ada tiga dimensi kepuasan karyawan, yaitu: (1) kepuasan merupakan respons emosional terhadap situasi kerja, (2) kepuasan sering ditentukan oleh seberapa baik hasil yang dicapai memenuhi atau melampaui harapan, dan (3) kepuasan mewakili beberapa sikap yang saling berhubungan.

Derajat suka atau tidak suka terhadap aspek pekerjaan dapat dinilai dalam bekerja, karena menurut Steeers (1996:389): "job satisfaction as a pleasurable or positive emotional state (affect) resulting from the appraisal (cognition) of one's job orjob job experiences. Hypothesize that these feeling are associated with a perceived difference between what is expected as a fair return ... and what is experienced". Pendapat ini menegaskan bahwa penilaian yang disampaikan Steers identik dengan pendapat lainnya yaitu penilaian kepuasan kerja lebih ditekankan pada perbedaan antara apa yang diharapkan dan apa yang menjadi kenyataan dalam pengamalan bekerja.

Keterkaitan antara harapan dan kenyataan dengan suatu sikap yang efektif dijelaskan pula oleh Wexley dan Yukl (2002:208) bahwa "job satisfaction is a set of favorable or unfavorable feeling and emotions with which employees view their work". Dalam hal ini kepuasan kerja merupakan seperangkat kesadaran dan perasaan yang menunjang bagi karyawan dalam memandang pekerjaan mereka.Artinya aspek harapan dari karyawan, selain pemenuhan hasil kerja, juga kebutuhan lainnya seperti kebutuhan fisiologis, keamanan, sosial, penghargaan, dan aktualisasi diri.

Dalam manajemen, ada keyakinan bahwa karyawan yang puas dalam bekerja adalah karyawan yang produktif. Di sisi lain, kepuasan kerja menegaskan tentang apa 
yang membuat karyawan puas dengan pekerjaannya. Kepuasan kerja penting bagi karyawan dan manajer karena organisasi tidak ingin kehilangan karyawan yang terampil dan produktif.

Fraser (1983:188) menyatakan masalahnya dari segi orientasi ekstrinsik dan intrinsik, yaitu apakah karyawan terlihat dalam pekerjaan terutama sebagai suatu cara untuk memperoleh kepuasan di luar pekerjaannya atau memperoleh kepuasan dari pekerjaan itu sendiri. Karyawan merasa memiliki kepuasan kerja jika memiliki persepsi bahwa imbalan yang diterimanya atas pelaksanaan pekerjaan melebihi tenaga dan ongkos individu yang telah dikeluarkannya, dan selisih yang masih ada cukup untuk menjalani hidupnya

Kepuasan kerja adalah suatu keadaan yang bersegi banyak, beberapa segi lebih memuaskan dibanding yang lain. Kepuasan kerja biasanya hanya melukiskan suatu rerata hasil dari perbandingan beberapa keadaan dari suatu saat tertentu.Tidak ada suatu yang mutlak karena segalanya terbatas. Yang paling baik kita katakan adalah bahwa pada suatu saat tertentu seorang karyawan merasa lebih puas dengan pekerjaannya dari pada saat yang lain.

Luthans (2002: 231-232) yang mengutip pendapat Schemerhorn ada enam faktor yang mempengaruhi kepuasan kerja, yaitu: (1) the work it self, suatu pekerjaan memerlukan keterampilan tertentu; sukar tidaknya suatu pekerjaan dan perasaan seseorang bahwa keahliannya dibutuhkan dalam melakukan pekerjaan dapat meningkatkan atau mengurangi kepuasan kerja; (2) promotion opportunites, faktor yang berhubungan dengan ada tidaknya kesempatan untuk meningkatkan atau mengurangi kepuasan kerja; (3) promotion carrier, faktor yang berhubungan dengan ada tidaknya kesempatan untuk peningkatan karir selama bekerja; (4) supervision, penyelia yang baik yang mau menghargai pekerjaan bawahannya; (5) coworkers, faktor hubungan antara sesama pegawai yang sama maupun berbeda jenis pekerjaan; dan (6) pay, faktor pemenuhan hidup (seperti upah) yang dianggap layak.

Selanjutnya Robbins (2003:153) mengemukakan faktor-faktor yang mempengaruhi kepuasan kerja adalah: (1) pekerjaan yang menantang secara mental, (2) ganjaran yang pantas, (3) kondisi kerja yang mendukung, dan (4) reken kerja yang mendukung. Keempat faktor ini merupakan tantangan yang mungkin dapat dilaksanakan dengan baik oleh pimpinan, yang membuat karyawan lebih tertarik untuk melaksanakan pekerjaan mereka.

Spector (1997:30-53) mengklasifikasikan anteseden kepuasan kerja menjadi dua kategori utama, yaitu: anteseden ingkungan kerja dan faktor-faktor yang mempengaruhi lingkungan kerja; dan anteseden faktor individu, terutama berkaitan dengan kepribadian dan pengalaman. Sementara Mullins (2005: 704) menemukan bahwa faktor-faktor khusus yang mempengaruhi kepuasan kerja meliputi teknologi informasi, stress dalam pekerjaan, organisasi kerja, job design, pendekatan organisasi, keseimbangan kerja dan keseimbangan hidup, fleksibilitas pengaturan kerja, dan faktor kontekstual.

Berdasarkan uraian di atas maka dapat disintesiskan bahwa kepuasan kerja yang dimaksud dalam penelitian ini adalah rentang perasaan senang sampai tidak senang yang dirasakan karyawan terhadap berbagai aspek pekerjaan, meliputi gaji, promosi, teman kerja, penghargaan, supervisi atasan. 
Kepemimpinan. Ricard L. Daft (2005:4) mendefinisikan kepemimpinan sebagai sebuah hubungan yang saling mempengaruhi di antara pemimpin dan pengikut (bawahan) yang menginginkan perubahan nyata yang mencerminkan tujuan bersama. Sedangkan menurut Colquitt, Jeffery dan Wesson(2009:474), kepemimpinan adalah penggunaan kekuatan dan pengaruh untuk mengarahkan bawahan mencapai tujuan. Menurut Hatch, Kostera, dan Kozminski (2006: 49-68) observasi mutakhir tentang pemimpin organisasi minimal memiliki tiga "wajah" (1), yaitu manajer (disiplin, rasional, mengorganisasi, mengontrol, intelek, strategis, pengambil keputusan), (2) artis (memiliki rasa ingin tahu, mandiri, kreatif, emosional, pembaharu), dan (3) imam (etika, murni, empati, menginspirasi, suci). Dalam dunia bisnis, pemimpin menghadapi perubahan peran, bergerak dari fokus lokal ke global, mengikuti perkembangan pasar, mempelajari inovasi, lebih terbuka, selalu memperhatikan kualitas, dan membangun jaringan.

Satu pendekatan kepemimpinan yang baru aktual adalah teori Full-Range sebagai dikemukakan oleh Bernard Bass dan Bruce Avolio (1990:132). Mereka mengemukakan bahwa perilaku kepemimpinan berada sepanjang kontinum dari "laissez-faire-kepemimpinan transaksional-kepemimpinan transformasional". Teori kepemimpinan laissez-faire adalah cara yang buruk sekali untuk banyak manajer. Suatu meta analisis telah menyimpulkan bahwa laki-laki lebih banyak menggunakan tipe kepemimpinan ini dari pada wanita (Eagly, Schmidt, dan Engen: 2003:569-591). Kepemimpinan transaksional dan transformasi berhubungan secara positif dengan variasi sikap dan perilaku karyawan dan menunjukkan apek-aspek yang berbeda dari keberadaan pemimpin yang baik. Kepemimpinan transaksional fokus pada menjelaskan peran karyawan dan pengakuan tugas dan menyediakan pengikut dengan hadiah positif dan negatif dalam pencapaian kinerja. Kepemimpinan transaksional menekankan pada kegiatan manajerial dasar seperti menetapkan tujuan, memonitor kemajuan menuju pencapaian tujuan, dan menghukun dan memberi hadiah untuk level tujuan yang capai mereka. Jadi, pada dasarnya kepemimpinan transaksional menggunakan motivasi ekstrinsik dalam peningkatan produktivitas karyawan. Kepemimpinan transformasional adalah kepemimpinan yang memunculkan kepercayaan, mengembangkan kepemim-pinan bersama orang lain, memperlihatkan pengorbanan diri dan melayani sebagai agen moral, menfokuskan pada diri mereka dan pengikut secara objektif dan mementingkan kebutuhan kelompok kerja secara cepat (Dumdum, 2002:38). Kepemimpinan transformasional menghasilkan

perubahan dan hasil organisasi yang signifikan sebab jenis kepemimpinan ini menciptakan motivasi intrinsik yang tinggi, kepercayaan, komitmen, dan loyalitas dari pengikut.

Teori kepemimpinan yang sedang berkembang seperti kepemimpinan LMX (model pertukaran pemimpin-pengikut) mengacu pada pengembangan hubungan dyadic (dua arah) antara manajer dan laporan yang mereka terima. Model ini sangat berbeda model-model sebelumnya yang fokus pada kualitas hubungan antara pemimpin dengan pengikut, yang dipertentangkan dengan perilaku atau sifat pemimpin dan pengikut. Model LMX didasarkan pada asumsi bahwa pemimpin mengembangkan hubungan satu dengan satu yang unik dimana masing-masing orang melapor kepada mereka.Ilmuwan perilaku menyebutkan hubungan ini sebagai vertical dyad. Pembentukan vertical dyad terjadi melalui proses yang alamiah, dihasilkan dari usaha pemimpin untuk mendelegasikan dan membuat bentuk pekerjaan. Hasil dari 
proses ini adalah dua tipe yang berbeda dari pertukaran hubungan pemimpin-pengikut diharapkan berkembang.

Berdasarkan uraian di atas maka disintesiskan bahwa kepemimpinan adalah perilaku atasan dalam mendorong dan mempengaruhi bawahan untuk mencapai tujuan yang telah ditetapkan dengan indikator perilaku/gaya: memperjelas jalur-tujuan, berorientasi prestasi, menfasilitasi kerja, mendukung bawahan, menfasilitasi interaksi, mengambilan keputusan berorientasi kelompok, membangun jaringan kerja, dan perilaku berbasis nilai.

Disain Pekerjaan. Disain pekerjaan (job design) telah menjadi isu menarik karena telah dianalisis dari berbagai sudut pandang seperti sosiologi, ekonomi, psikologi, dan kewirausahaan. Menurut Griffin (1987:299-300) disain pekerjaan adalah spesifikasi dari aktivitas yang berhubungan dengan tugas karyawan. Lebih lanjut ditegaskan bahwa tingkat spesialisasi yang tinggi dapat menambah efisiensi, tetapi juga dapat mengurangi kepuasan dan motivasi. Oleh karena itu, manajer perlu mencari alternatif untuk melakukan spesialisasi pekerjaan, mencariai cara untuk mendisain pekerjaan yang dapat menjaga kepuasan dan motivasi karyawan untuk bekerja lebih baik.

Gibson, et al (2006:368) menjelaskan bahwa disain pekerjaan mengacu pada proses dimana manajer membagi tugas-tugas dan tanggungjawab secara individu, sementara disain ulang pekerjaan adalah proses dimana manajer mempertim-bangkan ulang apa yang diharapkan dapat dikerjakan oleh karyawan. Dengan demikian, disain pekerjaan mengacu pada seluruh usaha yang dilakukan manajer untuk menciptakan pekerjaan apa yang dasar (wajib) dan apa yang berikutnya agar tercapai tujuan yang diinginkan.

Fred Luthans (2008:346) mendefisikan disain pekerjaan sebagai cara-cara yang digunakan manajemen dalam mengem-bangkan isi pekerjaan, meliputi seluruh tugas yang relevan sebagai proses dimana pekerjaan dikonstruksi dan direvisi. Melalui analisis pekerjaan telah diperkenalkan deskripsi pekerjaan dan spesifikasi pekerjaan karena organisasi dapat menggunakan informasi itu untuk mendisain pekerjaan atau mendisain ulang pekerjaan.

Tipe pekerjaan yang sama yang terspesialisasi telah umum digunakan di perusahaan, bank, kantor, rumah sakit, sekolah dan berbagai jenis organisasi. Spesialisai yang tinggi dan pekerjaan yang distandardisasi sangat efisien dan menuntun pada

tingkat yang tinggi dalam mengontrol karyawan. Sampai saat ini, sedikit orang mempertanyakan pendekatan rekayasa tradisional terhadap disain pekerjaan. Manajemen puncak dapat menetapkan dan mengetahui dengan segera biaya yang disimpan dari rekayasa pekerjaan; akan tetapi pengaruhnya terhadap kualitas, ketidakhadiran, berhenti, secara umum dapat diabaikan. Bahkan rekayasa merenggangkan lingkungan kerja dengan padatnya fisik (misalnya, modul kerja yang padat) dapat membuat arti dari kondisi biaya, tetapi studi akhir-akhir ini menemukan bahwa ruang kerja yang sumpek menambah kemungkinan untuk berhenti, kelambatan, dan kepuasan kerja yang rendah (May, Oldham dan Rathert, 2005:21-33).

Mendisain pekerjanan adalah merubah isi atau proses pekerjaan spesifik untuk meningkatkan kepuasan kerja dan prestas kerja. Disain pekerjaan digunakan bila manajer curiga bahwa jenis pekerjaan karyawan atau karakteristik lingkungan kerja menyebabkan masalah motivasional. Aktivitas lanjutan dari disain pekerjaan juga disebut sebagai mendesain ulang kerja, mengacu pada sejumlah kegiatan yang melibatkan perubahan dari pekerjaan khusus atau sistem saling ketergantungan 
pekerjaan dengan maksud memperbaharui kualitas pengalaman kerja karyawan dan produktivitas kerja mereka (Bowdith \& Buono, 1985:210). Satu tim peneliti (Champion dan Thayer, 1985:29-43) telah menguji variasi metode untuk melaksanakan disain pekerjaan dan mengintegrasikannya kepada satu kerangka kerja interdisiplin yang berisi empat pendekatan utama: mekanistik, motivasional, biologis, dan gerakan perseptual. Masing-masing pendekatan ini menekankan pada hasil yang berbeda.

Pendekatan motivasional terhadap disain pekerjaan berusaha meningkatkan reaksi perasaan dan sikap karyawan seperti kepuasan kerja dan motivasi instrinsik maupun hasil perilaku utama seperti ketidakhadiran, berhenti, dan kinerja (Workman dan Bommer, 2004:317-337). Ada empat teknik kunci pendekatan motivasional, yaitu: job enlargement, job rotation, job enrihment, dan the job characteristic model. Model karakteristik karyawan, menurut Hackman dan Oldham (1975:53), memainkan peran utama dalam mengem-bangkan pendekatan ini. Peneliti ini mencoba menetapkan bagaimana suatu pekerjaan tertentu dapat disusun sebaik mungkin sehingga karyawan termotivasi secara internal atau intrinsik.

Tiga karakteristik pekerjaan dikombinasikan untuk menentukan kebermaknaan pengalaman dalam bekerja, yaitu: pertama, Variasi keterampilan. Keluasan pekerjaan memerlukan individu untuk melakukan tugas yang bervariasi dengan menggunakan keterampilan dan kemampuan yang berbeda. Identitas tugas. Keluasan pekerjaan memerlukan individu untuk melakukan pekerjaan yang dapat diidentifikasi secara komplit. Dengan kata lain, identitas tugas tinggi jika seseorang mengerjakan suatu produk atau proyek dari awal sampai akhir dan menunjukkan hasil yang dapat dilihat. Kedua, Signifikansi tugas. Keluasan pekerjaan mempengaruhi kehidupan orang lain di dalam atau di luar organisasi. Rasa tanggungjawab yang dialami ditunjukkan oleh otonomi.Keluasan pekerjaan mensyaratkan individu untuk mengalami kebebasan, kemandirian, dan keleluasaan dalam menjadual dan menentukan prosedur yang digunakan dalam menyelesaikan pekerjaan. Ketiga, untuk mengetahui hasil kerja diperlukan umpan balik.Keluasan pekerjaan dimana seseorang menerima informasi yang jelas dan langsung tentang bagaimana efektifnya dia melaksanakan pekerjaan. Hackman

dan Oldham mengakui bahwa setiap orang tidak menginginkan suatu pekerjaan yang mengandung bilangan yang tinggi dari lima karakteristik pekerjaan inti. Mereka memasukkan kesimpulan ini kepada model mereka dengan mengidentifikasi tiga atribut yang mempengaruhi bagaimana individu menanggapi pengayaan pekerjaan (Kreitner dan Kinicki, 2007:257).

Berdasarkan uraian di atas dapat disintesiskan bahwa disain pekerjaan adalah segala kegiatan atau tindakan yang dilakukan manajer dalam menetapkan tugas dan tanggungjawab karyawan agar tugas karyawan terlaksana dengan sebaik-baiknya. Indikator yang digunakan meliputi variasi keterampilan, identitas tugas, keberartian tugas, otonomi, dan umpan balik.

Iklim Organisasi. Miller (1987:128) menegaskan bahwa iklim organisasi adalah nilai dan semangat yang mendasar dalam cara mengelola serta mengoperasikan organisasi. Nilai-nilai itu merupakan keyakinan yang dipegang teguh dan kadang-kadang tidak terungkap. Sehubungan dengan itu, Robert Kreitner (1995:285-286) mengungkapkan bahwa bentuk iklim organisasi dapat berupa kolektivitas, emosional, uraian sejarah, simbol-simbol, dinamis dan ambisi organsasi. Nilai-nilai dan semangat ini akan mendasari sifat organisasi dalam usaha menjawab tantangan. 
Daniel Denison (1990:157) menyatakan bahwa iklim organisasi adalah kekuatan dan potensi yang dimiliki suatu organisasi untuk melakukan koordinasi dan kontrol terhadap perilaku anggota organisasi. Dengan demikian, kuatnya suatu iklim organisasi yang baik akan berpengaruh dengan makin meningkatnya mutu informasi serta koordinasi perilaku.

Laurie J. Mullins (2005:899) menegaskan bahwa manajemen memiliki tanggung jawab untuk menciptkan iklim yang membuat orang termotivasi bekerja dengan sungguh-sungguh dan efektif. Lebih lanjut dia menyatakan iklim organisasi berhubungan dengan "atmosfir" yang menaungi organisasi, tingkat moral, kekuatan perasaan dan tanggungjawab, pemeliharaan dan niat baik diantara anggota organisasi. Iklim tersebut akan mempengaruhi sikap anggota-anggota organisasi dan pada gilirannya meme-ngaruhi kinerja dan hubungan antar pribadi. Beliau juga menegaskan bahwa budaya organisasi berpengaruh terhadap iklim organisasi.

Stephen P. Robbins (1990:196-197) menyatakan iklim organisasi memiliki lima manfaat yaitu: (1) manfaat terhadap organisasi, (2) manfaat terhadap pengembangan organisasi, (3) manfaat terhadap pengembangan sumber daya manusia, (4) manfaat terhadap pengembangan usaha, dan (5) manfaat terhadap pelanggan. Iklim organisasi juga memupuk loyalitas dan dedikasi karyawan pada organisasi. Dengan iklim organisasi yang kuat diharapkan akan memberikan citra positif iklim dan kemapanan organisasi. Citra kemapanan organisasi penting, selain akan menunjukkan perbedaannya dengan organisasi lain, kemapanan juga akan menarik perhatian pegawai yang berbobot masuk dalam jajaran organisasi. Pada gilirannya, para pegawai ini dapat dikembangkan menjadi karyawan profesional.

Robert D. Pritchard, dan Bernard W. Karasick (1983:126-146) menguji sebelas dimensi iklim organisasi dalam dua jenis organisasi yang berbeda. Kesebelas dimensi dimaksud adalah: (1) otonomi, (2) konflik lawan kerjasama, (3) hubungan sosial,

(4) struktur tugas, (5) level penghargaan, (6) penghargaan berdasar-kan kinerja, (7) dorongan untuk berhasil, (8) polarisasi status, (9) fleksibilitas dan inovasi, (10) sentralisasi keputusan, dan (11) dukungan. Sementara, James F. Gavin dan John G. Howe (1986: 95-103) mengemukakan enam dimensi iklim organisasi, yaitu: (1) kejelasan dan efisiensi struktur dalam hal kebijakan dan petunjuk, (2) hambatan dalam pelaksanaan tugas, (3) penghargaan yang diberikan secara tepat dan benar, (4) semangat yang diekpressikan dalam bentuk loyalitas, kerjasama, dan persabahatan dalam bekerja, (5) kepercayaan dan pertimbangan manajemen yang diberikan kepada karyawan, dan (6) tantangan dan resiko, dalam arti manajemen memberikan standar kinerja yang tinggi dan keberanian mengambil resiko.

Secara umum, menurut Laurie J. Mullins (2005:900), iklim organisasi yang sehat diharapkan memiliki ciri-ciri berikut: (1) Adanya integrasi tujuan organisasi dan tujuan pribadi/anggota; (2) Struktur organisasi yang lebih tepat didasarkan pada permintaan sistem sosio-teknis; (3) Demokrasi memberikan kesempatan penuh untuk berpartisipasi; (4) Keadilan diterapkan dalam kebijakan dan praktek pembinaan sumber daya manusia; (5) kepercayaan bersama, pertimbangan dan dukungan dari berbagai level orgnisasi; (6) Diskusi terbuka tentang konflik dan berusaha menghindari konfrontasi; (7) Peri-laku manajer dan gaya kepemimpinan cocok dengan situasi pekerjaan;(8) Pene-rimaan kontrak psikologis antara individu dan organisasi; (9) Pengakuan kebutuhan dan harapan karyawan dalam bekerja; (10) Sistem yang adil dalam penghargaan berdasarkan pengakuan secara positif; (11) Peduli terhadap kualitas hidup pekerjaan dan disain pekerjaan; (12) Kesempatan dalam mengembangan dan memajukan karir; 
dan (13) Memiliki identitas dan loyalitas terhadap organisasi dan merasa penting dan dihargai organisasi.

Berdasarkan uraian di atas dapat disintesikan bahwa yang dimaksud dengan iklim organisasi adalah persepsi karyawan tentang suasana di lingkungan dalam organisasi tempat mereka bekerja yang menjadi citra organisasi tersebut, dengan indikator: lingkungan fisik, penghargaan akan prestasi, fleksibilitas, kesempatan berpartisipasi, hubungan sosial, keterbukaan komunikasi, kerjasama, dan kejelasan tugas.

\section{METODE PENELITIAN}

Penelitian ini dilakukan pada tanggal di Universitas Negeri Medan (UNIMED). Penelitian ini didahului dengan mengurus izin penelitian, melakukan uji coba instrumen penelitian, menganalisis data uji coba, melakukan penyempurnaan instrumen.Uji Coba instrumen penelitian dilakukan pada tanggal 24-30 Juni 2008.Pelaksanaan penelitian dilaksanakan dari tanggal 13-30 Agustus 2008.

Metode yang digunakan dalam penelitian ini adalah metode survai kausal karena metode ini dianggap tepat untuk menjelaskan sebuah fenomena sosial. Populasi penelitian ini adalah tenaga penunjang akademik golongan II dan III di Universitas Negeri Medan. Sampel penelitian yang ditetapkan dengan simple random samplin). Untuk memperoleh sampel 79 orang dari 359 orang populasi digunakan rumus Taro Yamane.

\section{HASIL PENELITIAN DAN PEMBAHASAN}

\section{Kepemimpinan Kepala Sekolah terha dap Motivasi Kerja}

Hasil pengujian hipotesis pertama menunjukkan bahwa kepemimpinan kepala sekolah berpengaruh positif yang signifikan terhadap motivasi kerja guru. Dengan demikian kepemimpinan kepala sekolah merupakan variabel penting dalam meningkatkan motivasi kerja. Hasil penelitian ini mendukung teori motivasi yang dikemukakan oleh Maslow, bahwa jika seorang pemimpin termasuk kepala sekolah ingin mening- katkan prestasi guru, kepala sekolah harus tahu betul dan memahami kebutuhan-kebutuhan para guru sebagai bawahannya di tingkatan manakah mereka berada. Sehingga pemimpin dapat dengan mudah dan tepat memberi motivasi kepada guru agar kerjanya baik sehingga dapat merasakan akan kepemimpinannya dan dapat meningkatkan prestasi kerjanya. Pemimpin menjadi efektif karena motivasi guru meningkat.

Dalam meningkatkan kepemimpinan kepala sekolah sesuai dengan teori motivasi Maslow bahwa kepala sekolah dalam menjalankan kepemimpinannya harus mengetahui betul kemauan para guru, agar kebijakannya tepat sasaran dan guru termotivasi dalam mengajarnya penuh semangat yang tinggi. Kebijakan kepala sekolah dalam menentukan jadwal pelajaran yang merata, seimbang dan profesional sesuai dengan pengampuan guru dalam SKnya dan lebih mengedepankan kualitas ketimbang kedekatan. Jam mengajarnya yang seimbang, adil antara guru yang satu dan guru yang lainnya.

Fakta di lapangan menunjukkan sesuai dengan hasil penelitian bahwa kepemimpinan kepala sekolah ber- pengaruh positif terhadap motivasi kerja. 


\section{Kecerdasan Emosional terhadap Motivasi Kerja}

Hasil pengujian hipotesis kedua menunjukkan bahwa kecerdasan emosional berpengaruh positif yang signifikan terhadap motivasi kerja guru. Dengan demikian kecerdasan emosional merupakan variabel penting dalam meningkatkan motivasi kerja. Hasil penelitian ini mendukung teori yang dikemukakan oleh Rita L. Atkinson, Richard C. Atkinson dan Ernes R. Hilgart yang menyebutkan bahwa motivasi dan emosi mempunyai kaitan yang erat. Emosi sering kali memotivasi tindakan-tindakan. Mengacu pada pengertian tersebut di atas, menggambarkan bahwa emosi memiliki arti penting bagi individu karena dapat menjadi pengaktif dan pendorong untuk melakukan atau bereaksi terhadap sesuatu.

Guru yang memiliki kecerdasan emosional yang tinggi dapat mendorong guru lain untuk meningkatkan motivasi kerja, emosi mempunyai kaitan erat dengan motivasi. Guru-guru di SMA Negeri Kota Cirebon secara umum sikapnya baik-baik, dalam mengajar mereka memegang kode etik guru, yaitu dengan tertibnya mengajar ketika masuk ruangan kelas tidak saling berebut sesuai dengan jadwal yang sudah ditentukan oleh kepala sekolah. Guru dengan guru saling menghormati pada saat ketemu di kantor, mereka saling menyadari dan menghargai sesama guru dan tenggang rasa dalam menja- lankan tugas guru, memiliki loyalitas yang tinggi kepada atasan yaitu kepala sekolah, memiliki semangat yang tinggi dalam bekerja selalu tepat waktu. Persaingan guru dengan guru dalam sekolah cukup sehat dan dinamis, mereka saling memberi motivasi, beker ja sama dalam tugas, apabila ada guru yang dipromosikan oleh kepala sekolah menjadi wali

kelas, guru lain turut senang karena temannya memiliki prestasi yang baik dalam melaksanakan tugas sehingga dipromosikan menjadi wali kelas.

\section{Kepemimpinan Kepala Sekolah terha dap Kepuasan Kerja}

Hasil pengujian hipotesis ketiga, menunjukkan bahwa kepemimpinan kepala sekolah berpengaruh positif yang signifikan terhadap kepuasan kerja guru. Dengan demikian kepemimpinan kepala sekolah merupakan variabel penting dalam meningkatkan kepuasan kerja guru. Hasil penelitian ini mendukung Teori Kepemimpinan Jalur Tujuan (Path Goal Leadership) yang dikembangkan oleh Robert J. House yang dikutip oleh Stephen P. Robbins, bahwa perilaku seorang pemimpin dapat diterima baik oleh bawahan sejauh mereka pandang sebagai suatu sumber dari kepuasan segera atau kepuasan masa depan.

Peranan seorang kepala sekolah dalam meningkatkan dan menurunkan kepuasan kerja guru sangat besar pengaruhnya. Hasil penelitian menunjukkan bahwa kepemimpinan kepala sekolah berpengaruh terhadap kepuasan kerja guru. Kepala sekolah dalam meningkatkan kepemimpinannya mem- perhatikan guru-guru yang berprestasi dalam kerjanya di sekolah untuk diusulkan kepada Kepala Dinas Kota Cirebon dipromosikan menjadi guru berprestasi melalui sistem seleksi di tingkat Kota Cirebon sampai ke tingkat nasional bagi yang seleksinya lulus diberi reward.

Adapun teknik-teknik kepala sekolah dalam meningkatkan kepuasan kerja guru bisa dilaksanakan dengan berbagai cara. Menurut Teori Jalur Tujuan (Path Goal Theory), Hause mengidentifikasikan ada empat gaya perilaku kepemimpinan dalam mencapai sasaran untuk memberikan kepuasan kerja guru yaitu pertama, directive, perintah kepemimpinan, memberikan bimbingan kepada guru-guru agar kerjanya baik. Kedua, partisipative, pimpinan (kepala sekolah) mendekati guru (sebagai bawahannya) dengan sungguh-sungguh meminta saran, pendapat, ide-idenya yang baik diserap agar 
dalam membuat keputusan tidak salah. Ketiga, Achievement Oriented (berorientasi prestasi) bagi guru-guru yang berprestasi diusulkan untuk dipromosikan menjadi modal keunggulan bagi sekolah, mendorong para guru untuk tampil menjadi tenaga guru yang berkualitas dan terbaik. Keempat, supportive (pendukung) pemimpin (kepala sekolah) menunjukkan kepeduliannya dengan para guru untuk meningkatkan kesejahteraannya, dengan sikap yang ramah dan memperlakukan semua sama, tidak dibeda-bedakan satu dengan yang lainnya.

Dalam menerapkan gaya tersebut tergantung situasi dan kondisi lingkungan. Dengan menggunakan dua variabel kemungkinan, kemungkinan faktor lingkungan di luar karyawan (guru) dan faktor pribadi karyawan (guru) itu sendiri dan sasaran atau tujuannya adalah kepuasan karyawan (guru). Dengan teori tersebut di atas, apa yang dikemukakan oleh Hause, kepala sekolah dapat menggunakan teori tersebut, untuk meningkatkan kepuasan kerja guru di SMA Negeri Kota Cirebon, dan hasil penelitian menunjukkan adanya pengaruh kepemimpinan kepala sekolah terhadap kepuasan kerja guru.

\section{Kecerdasan Emosional terhadap Kepuasan Kerja}

Hasil pengujian hipotesis keempat menunjukkan bahwa kecerdasan emosional berpengaruh positif terhadap kepuasan kerja guru. Namun pengaruh tersebut ternyata tidak signifikan secara statistik pada taraf nyata 5\%. Tapi meskipun demikian, ternyata kecerdasan emosional memberikan pengaruh langsung yang sangat besar terhadap kepuasan kerja, sesuai dengan teori yang dikemukakan oleh Salovey beliau membagi kecerdasan emosional ke dalam 5 wilayah utama, yaitu : 1. Mengenali emosi diri, 2. Mengelola emosi, 3. Memotivasi diri sendiri, 4. mengenali emosi orang lain, 5. Membina hubungan. Menurut teori tersebut, guru yang memiliki kecerdaan emosional yang tinggi dapat berkomunikasi dengan baik dalam kerjanya. Dalam hal ini guru akan merasa tentram dan nyaman berada didekatnya, apalagi kesejahteraannya diperhatikan oleh kepala sekolah. Mereka menebar kehangatan dan keterbukaan atau transparansi dengan cara yang tepat dan para guru dapat merasakan kepuasan dari hasil kerjanya, karena memiliki kecerdasan emosional yang tinggi. Sementara motivasi kerja kemudian berpengaruh terhadap kepuasan kerja guru. Dengan demikian, dapat dikatakan bahwa pengaruh kecerdasan emosional terhadap kepuasan kerja adalah secara tidak langsung.

\section{Motivasi kerja terhadap Kepuasan Kerja}

Hasil pengujian hipotesis kelima menunjukkan bahwa motivasi kerja berpengaruh positif yang signifikan terhadap kepuasan kerja guru. Dengan demikian motivasi kerja merupakan variabel penting dalam meningkatkan kepuasan kerja guru. Hasil penelitian ini mendukung teori yang dikemukakan oleh Abraham H. Maslow, bahwa dorongan atau motiv yang membuat orang bersemangat adalah harapan pemenuhan kebutuhan. Kebutuhan-kebutuhan di dalam diri setiap manusia ini tersusun dari suatu hierarki. Maslow telah mengembangkan suatu teori hierarki kebutuhan, teori motivasi yang paling dikenal baik. Ia menghipotesiskan bahwa di dalam diri semua manusia ada suatu jenjang pada umumnya muncul dalam model prediksi langkah tangga, itu dimulai dengan tingkatan kebutuhan yang paling rendah, yaitu kebutuhan fisiologis/phisiological (kebutuhan fisik) sampai kepada kebutuhan yang paling tinggi yaitu kebutuhan aktualisasi diri, seperti apa yang dikutip oleh Robert 
Kreitner. Pertama, kebutuhan fisik (physiological) seperti kebutuhan maka-nan, air, tidur dan sex. Pemenuhan kebutuhan ini memungkinkan seseorang dapat bertahan hidup. Kedua, kebutuhan keamanan/keselamatan (safety dan security) kebutuhan akan kebebasan dari ancaman, dari musuh. Ketiga, kebutuhan dicintai/mencintai (love), keinginan untuk dicintai dan mencintai. Keempat, penghargaan terhadap diri, yaitu kebutuhan untuk reputasi, gengsi dan pengakuan dari orang lain (esteem). Kelima, kebutuhan aktualisasi diri (self-actualization), yaitu kebutuhan tertinggi seseorang yaitu keinginan menjadi yang terbaik. Kepuasan kerja akan didapatkan jika kebutuhankebutuhan tersebut dapat terpenuhi.

\section{PENUTUP}

Kesimpulan: 1) Kepemimpinan berpengaruh langsung terhadap kepuasan kerja. 2) Disain pekerjaan berpengaruh positif terhadap kepuasan kerja. 3) Iklim organisasi pekerjaan berpengaruh positif terhadap kepuasan kerja. 4) Kepemimpinan berpengaruh positif terhadap iklim organisasi. 5) Disain pekerjaan berpengaruh positif terhadap iklim organisasi.

Implikasi: 1) Terjadinya peningkatan kepuasan kerja tenaga penunjang akademik di Universitas Negeri Medan diakibatkan oleh peningkatan kepemimpinan atasan. 2) Terjadinya peningkatan kepuasan kerja tenaga penunjang akademik di Universitas Negeri Medan diakibatkan oleh pengaturan disain pekerjaan yang baik. 3) Terjadinya peningkatan kepuasan kerja tenaga penunjang akademik di Universitas Negeri Medan diakibatkan oleh peningkatan iklim organisasi yang kondusif. 4) Terjadinya peningkatan iklim organisasi yang kondusif di Universitas Negeri Medan diakibatkan oleh peningkatan yang terjadi dalam kepemimpinan. 5) Terjadinya peningkatan iklim organisasi yang kondusif di Universitas Negeri Medan juga diakibatkan oleh peningkatan yang terjadi dalam disain pekerjaan.

Saran: 1) Diharapkan kepada pimpinan Universitas Negeri Medan, sebagai salah satu lembaga pelayanan publik di bidang pendidikan, dalam rangka meningkatkan kepuasan kerja tenaga penunjang akademik, tidak hanya menambah insentif, tetapi juga meningkatkan kualitas kepemimpinan atasan dari tenaga penujang akademik. 2) Diharapkan kepada para Kepala Bagian dan Kepala Sub Bagian di lingkungan Universitas Negeri Medan untuk dapat membuat disain pekerjaan bawahan dan mendisain ulang pekerjaan mereka sesuai dengan tantangan yang dihadapi Universitas dalam pelayanan publik. 3) Diharapkan kepada para Kepala Bagian dan Kepala Sub Bagian di lingkungan Universitas Negeri Medan untuk dapat menciptakan iklim organisasi atau lingkungan internal organisasi yang kondusif. 4) Diharapkan kepada para peneliti maupun pemerhati kepuasan kerja karyawan, agar hasil penelitian ini dapat dijadikan sebagai bandingan atau pengayaan informasi tentang faktor-faktor yang mempengaruhi kepuasan kerja, dan agar dilakukan penelitian tentang variabel lain yang mempengaruhi kepuasan kerja. 5) Diharapkan Departemen atau Lembaga pemerintah sebagai lembaga pelayanan publik agar melakukan survai nasional tentang kepuasan kerja pegawai negeri dan kepuasan konsumen guna memperoleh potret kepuasan kerja mereka dan mengantisipasi serta menghindari perilaku kontra produktif, seperti korupsi, dan lain-lain. 


\section{DAFTAR PUSTAKA}

Colquitt, Jason. A. Jeffery A. Lepine and Michael Wesson. Organizational Behavior. New York: McGraw Hill Company, 2009.

Gibson, James L. John M. Ivancevich, James H. Donnelly, Jr, Robert Konopaske, Organization: Behavior, Structure, Process. Boston: McGraw Hill Companies, Inc, 2006.

Greenberg, Jerald, dan Robert A. Baron, Behavior in Organization, understanding and managing the human side of work, $5^{\text {th }}$. ed. Englewood Cliff: Prentice Hall, 1995.

Kreitner, Robert and Angelo Kinicki, Organizatinal Behavior, $7^{\text {th }}$ ed. New York: McGrawHill/Irwin, 2007.

Mullins, Laurie J. Management and Organizational Behavior, $7^{\text {th }}$ ed. London: Prentice Hall, 2005.

Richard L. Daft, The Leadership Experience, 3 rd ed,. Cincinnati: Thomson-South Western, 2005.

Robbins, Stephen P. Organizational Behavior, 10 thed. Englewood Cliff: Prentice Hall, 2003.

Robbins, Stephen P. and Mary Coulter.Management. New Jersey: Prentice Hall, 2007.

Schermerhorn, Jr, John R. James G.Hunt and Richard N. Osborn, Organizational Behavior. Eighth Edition. New Jersey: John Wiley \& Sons, Inc., 2003.

Spector, Paul E. Job Satisfaction: Application, Asessment, Causes, and Consequences. (Thousand Oaks, California: Sage Publications, 1997. 
